\title{
Primary Erythromelalgia
}

National Cancer Institute

\section{Source}

National Cancer Institute. Primary Erythromelalgia. NCI Thesaurus. Code C125383.

An autosomal dominant condition caused by mutation(s) in the SCN9A gene, encoding sodium channel protein type 9 subunit alpha. It is characterized by episodes of recurrent warmth, redness, and burning sensations in the extremities. 